\title{
A New British Antarctic Expedition
}

\section{Author(s): E. H. Shackleton}

Source: The Geographical Journal, Vol. 29, No. 3 (Mar., 1907), pp. 329-332

Published by: geographicalj

Stable URL: http://www.jstor.org/stable/1776716

Accessed: 20-04-2016 22:14 UTC

\section{Your use of the JSTOR archive indicates your acceptance of the Terms \& Conditions of Use, available at}

http://about.jstor.org/terms

JSTOR is a not-for-profit service that helps scholars, researchers, and students discover, use, and build upon a wide range of content in a trusted digital archive. We use information technology and tools to increase productivity and facilitate new forms of scholarship. For more information about JSTOR, please contact support@jstor.org.

The Royal Geographical Society (with the Institute of British Geographers), Wiley are collaborating with JSTOR to digitize, preserve and extend access to The Geographical Journal 
over Duwoni (or Mount Baker). This summit is rightly known as "Johnston's Duwoni," since it is the peak he drew from Ibanda. But some confusion has arisen from the fact that, when at the head of the Mobuku valley, Sir H. Johnston thought the summits to the east of the icefall were identical with those he had seen from Ibanda (see Johnston's 'The Uganda Province,' vol. 1, pp. 158 and 187).

On the other hand, Dr. Wollaston's report led me into the erroneous belief that the highest peaks were not on the watershed. The Duke has cleared up and established the topography of the inmost portion of the group by his discovery of the importance of the long Bujuku valley. When we passed its opening mists and rain-storms bid the landscape; but it is strange that it should altogether have escaped the British Museum party, for whom it might have proved a happy hunting-ground during the weeks they spent at Bihunga. The Duke has also shown that all previous travellers were in error in regarding the crest at the head of the Mobuku glacier (Moore glacier) as part of the watershed.

In the foregoing remarks I have been greatly assisted by the superb panoramas and photographs presented to me by my former companion in the Himalaya, Signor Vittorio Sella. The perfect panorama from King Edward's peak (Kiyanja) is a masterpiece of mountain photography, which rivals his "Caucasus from Elbruz," or his "Kangchenjunga from the North-West."

It is not uncommon, even in unexpected quarters, to find it assumed that "a mountaineering party" is incapable of rendering any return to geography and science. Mountaineers may point, in Ruwenzori, to an instance where they have succeeded, after many experienced travellers, who were not mountaineers, had failed, in lifting the veil of centuries and giving the world accurate knowledge of a most interesting and fascinating region-the Snows of the Nile. The Duke of the Abruzzi and Signor Sella have done for the rcgion above the snow-level what Sir H. Johnston had previously done for the lower zone of forests and flowers.

\section{A NEW BRITISH ANTARCTIC EXPEDITION.}

\section{By E. H. SHACKLETON.}

I AM at present organizing a new expedition to the South Polar Regions. My purpose is that this expedition should leave New Zealand at the end of January or beginning of February, 1908. The expedition will, unlike that of the Discovery, consist of a small shore party of nine to twelve men, who will winter at the winter quarters of the Discovery. The ship will either be a whaler, specially chartered or purchased, or a fullpowered steamer, capable of doing 10 knots, which will not leave New Zealand until February, when the sea in the South is free of ice. On landing the party, the vessel will return to New Zealand, and the charter will be up until the following year. There will thus be no risk of the ship being frozen in, and there will be no responsibility to those at home.

The funds at present at our disposal admit of the following programme.

No. III.-MarCH, 1907.] 
The shore party of nine or twelve men will winter with sufficient equipment to enable three separate parties to start out in the spring. One party will go east, and, if possible, cross the barrier to the new land known as King Edward the Seventh's Land, follow the coast-line there south, if the coast trends south, or north if north, returning when it is considered necessary to do so. T'he second party will proceed south over the same route as that of the southern sledge party of the Discovery; this party will keep from 15 to 20 miles from the coast, so as to avoid any rough ice. The third party will possibly proceed westward over the mountains, and, instead of crossing in a line due west, will strike towards the magnetic pole.

'The main changes in equipment will be, that Siberian ponies will be taken for the sledge journeys both east and soutb, and also a specially designed motor-car for the suuthern journey. A North China or Siberian pony is capable of dragging $1800 \mathrm{lbs}$. on a food basis of $10 \mathrm{lbs}$. per day. A dog drags 100 lbs. at the outside, and requires over $2 \mathrm{lbs}$. of food a day. Therefore, one pony drags as much as eighteen dogs at less than one-third in weight of provision, and can travel comfortably 20 to 25 miles a day.

The motor will be of a special type, taking into consideration the temperatures to be encountered and the surface to be travelled over. I would propose to take three or four ponies on the southern journey, and the motor-car. As long as the car continued to remain satisfactory, it alone would be used to drag our equipment and provisions. If it broke down and could not be fixed up, then the ponies would take over the load.

I would propose travelling at the rate of 20 to 25 miles a day, and feel assured that, providing the motor does its work, we could reach with it a point beyond $82^{\circ} 16^{\prime} \mathrm{S}$. I intend, every 100 miles, to drop a sledgeload of provision and equipment, so that, in the event of every means of traction breaking down except by men, we would only have 100 miles to go between each depôt on return. The geographical south pole is 731 miles from winter quarters, and allowing that we only go with the motor to $82^{\circ} 16^{\prime}$, we would then practically be starting for the remaining 464 miles as fresh as if we were starting from the ship. What lies beyond $83^{\circ} \mathrm{S}$. we cannot tell, but I am of opinion that we can follow the trend of the southern mountains for a very long way south, before they turn either east or west. Should they turn to the eastward, and we find it impossible to get over them with the ponies, we would pull the sledges ourselves up the nearest available glacier. If no way up the mountains is found, we would continue following them round to the eastward, until we found it necessary to return towards winter quarters. If, on the other hand, the mountains turned to the west, we would continue straight south, and, if the surface were favourable, would increase the distance between our depôts to 150 miles, to 
admit of a more extended journey. On reaching the geographical pole, we should strike at an angle about north-west, and so pick up the mountains to the westward. When it became necessary to return, we would then strike due east, and begin picking up our last depôts.

I do not intend to sacrifice the scientific utility of the expedition to a mere record-breaking journey, but say frankly, all the same, that one of my great efforts will be to reach the southern geographical pole. I shall in no way neglect to continue the biological, meteorological, geological, and magnetic work of the Discovery. Should we have sufficient funds, we would land a small party of men at the nearest available point to the south magnetic pole. When the time came for sledging, they would move over the mountains towards the pole, taking careful observations the whole time, and if good fortune attends them and they reach the pole, they would survey the magnetic area as far as possible. During their winter stay in the vicinity of Mount Melbourne, the magnetic instruments would be running, and the meteorological observations would be taken at the same time as they would be taken in our winter quarters, so that a comparison could be made afterwards. If possible, in the winter quarters, where also magnetic observations will be taken, we would have a small launch in use for the remainder of the summer, in which the biologist could do marine dredging in a more continuous way than we were able to do on the Discovery. As regards geology, the wintering party by Mount Melbourne would have a new field to work on, and I would propose that careful observations and collections be made in all departments, the results of which could be worked out by those at home more qualified to do so than the field workers; and if the expedition proves a success, we intend to publish in as complete a manner as possible all the scientific results. By this means I would hope to have an expedition that will not only be successful in the field, but will make a mark in the scientific world on its return.

On the return of the vessel in February, 1909, the first party to be picked up would be that in the far south; the second party, at Mount Melbourne, would be picked up on the return. Should I only have a full-powered steamer of steel, it would not be possible for me to risk the approach to Mount Melbourne; but I hope through friends who are interested in this work to increase the scope of the expedition. Then, having a whaling vessel-which even now I may get-I propose, after picking up the party at Mount Melbourne, to proceed north of the Balleny islands, come down south again at the longitude where the Discovery turned north, and keep in as far south as possible to trace the north-western coast of Wilkes' Land, going as far west as possible before it is necessary to turn north. If we could settle the exact coastline of Wilkes' Land, it would be a great help to geography. By the southern and eastern sledge journey we may possibly solve the problem 
of the great ice-barrier; by the journey along Wilkes' Land we may lay down a definite coast-line; by the charting of new mountains and discovery of new lands in the far south we aid geographical science; by the magnetic work we help not only the academic side of magnetic science, but we may help the mercantile community in the way of better variation charts.

As regards personnel this is not yet settled, but I hope that some of those with whom I was associated before will come again, so that their training and experience of from 1901-4 will be available. I would like to add that, if possible, during the winter, we should try and watch the breeding and nesting of the emperor penguins.

As regards equipment, which I have worked out, I can say but little now, and this is not the place for it; but such things as a cinematograph for showing the movements of the penguins, and a phonograph for recording their cries, will be amongst the things taken to give our countrymen at home a better knowledge of the natural history of the place.

\section{THE KINGSTON (JAMAICA) EARTHQUAKE.}

ON June 7, 1692, the island of Jamaica was visited by an earthquake of great violence and extent. Throughout the island destruction was general, houses were overthrown, fissures opened in the ground, the mountains were scarred with landslips, and at Port Royal, then the capital of the island, a tract of 1000 acres was submerged beneath the sea to depths of 4 to 6 fathoms, while other parts underwent little or no change of level. How far this subsidence was due to the settlement of unconsolidated surface deposits is uncertain, but the earthquake was evidently of the same type as the Californian one of last year or the Alaskan of 1899 ; there may well have been movement along fault lines, like those described by Messrs. Tarr and Martin in this Journal of July last, and in this way a considerable subsidence of one part of the town may have taken place while the rest was but little affected in this respect. Be this as it may, the area available for building was so much reduced that a part of the population had to migrate and establish itself at Kingston, which became in time the capital of the island, and now, by the irony of fate, was itself destroyed by an earthquake on January 14, 1907.

Though it has attracted as much attention, and filled as much space in the daily papers as the Californian and Chilian earthquakes of last 